\title{
Psychological Stress Among Mothers of Children with Autism Spectrum Disorder and Down Syndrome in the City of Kufra
}

\author{
Mansour Mohammed Ali Bopaeda 8(D) \\ Lecturer, Department of Clinical psychology, Faculty of Arts \& Science Kufrah, Benghazi University, Libya \\ $\square$ Corresponding Author: Mansour Mohammed Ali Bopaeda, E-mail: bopaedmansour@gmail.com
}

\begin{tabular}{|c|c|}
\hline ARTICLE INFORMATION & ABSTRACT \\
\hline Received: April 25, 2021 & Having a baby is a huge responsibility. It often happens that mothers, especially when \\
\hline Accepted: June 27, 2021 & they are having their first baby, feel stressed and incompetent in their role as mothers \\
\hline $\begin{array}{l}\text { Volume: } 2 \\
\text { Issue: } 1\end{array}$ & $\begin{array}{l}\text { even as their children normally grows. The purpose of this article is to identify the } \\
\text { general features of psychological stress among mothers of autism spectrum disorder }\end{array}$ \\
\hline DOI: $10.32996 / j m h s .2021 .2 .1 .4$ & $\begin{array}{l}\text { and Down syndrome and to identify the differences and relationship in psychological } \\
\text { stress between mothers of autism and down syndrome. In this study participated a }\end{array}$ \\
\hline KEYWORDS & group of mothers with children who have autism $(n=44)$ and mothers of children \\
\hline $\begin{array}{l}\text { Autism Spectrum Disorders; Down's } \\
\text { syndrome; Mothers; stress. }\end{array}$ & $\begin{array}{l}\text { with Down syndrome }(n=44) \text {. The findings made proved that the general features } \\
\text { of psychological stress are high Among mothers of autistic children, while it was low } \\
\text { among mothers of Down syndrome, there were also statistically significant } \\
\text { differences in the level of psychological stress between mothers of autism and Down } \\
\text { syndrome, and a correlation was found between mothers of autism and Down } \\
\text { syndrome at the level of significance }(0.01) \text {. }\end{array}$ \\
\hline
\end{tabular}

\section{Introduction}

Gray, (1987) defines "stress is a special psychological condition, an emotion which is associated with anxiety, difficulty in concentration and attention, behavior exterior change, tightening of teeth and hands, breathing hard, the gap in the stomach, dry mouth, increased heart rate, sleep disorder, and many others". According to many studies, there is a higher level of stress, anxiety, and depression in mothers who have children with autism than mothers who have children with Down syndrome or typical development. According to Sanders and Morgan, (2008), "parents of children with autism report more stress and find it harder to adapt than parents of children with Down syndrome. Meanwhile, parents of children with Down syndrome have more stress and find it harder to adapt with their children than parents of children with typical development".

By comparing parents of children with autism with parents of children with typical development and parents of children with other developmental problems, parents of children with autism have higher levels of stress, anxiety, depression, lower level of interaction in the family, and complains more about health status and consumption. This is reflected in difficulty communicating, behavior in social isolation, and taking care of themselves (Schieve, 2015). Woodgate, Ateah, Secco, (2016) describe parents of children with autism as they themselves living in an isolated world. Johnson, Brakes, Feetham, Simpson, (2011) also describe parents of children with autism are under stress and this can affect their physical and psychological.

Therefore, when the individual is exposed daily to sources of psychological pressures such as calamities, situations, or severe emotional shocks, he may bear this because there are differences between people in the ability to bear. In the face of these situations, his psychological and self-compatibility is disturbed, and hence the deduction of the research problem, which represents the psychological pressures of mothers of autism and Down syndrome.

\subsection{Questions of the Study:}

The main questions of this study are as follows:

1. What is the general characteristic of psychological stress among mothers of autism disorder?

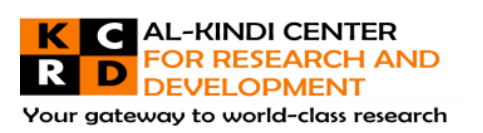

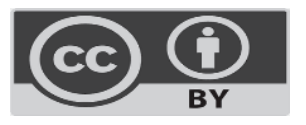

Published by Al-Kindi Center for Research and Development, United Kingdom. Copyright (c) the author(s). This open access article is distributed under a Creative Commons Attribution (CC-BY) 4.0 license 
2. What is the general characteristic of psychological stress among mothers of Down syndrome?

3. Are there statistically significant differences in psychological stress between mothers of autism disorder and Down syndrome?

4. Is there a relationship between psychological stress, as mothers of autism disorder and Down syndrome realize?

\subsection{Aims of the study:}

The main aims of this study are the following:

1. To recognize the general features of psychological stress among mothers of autism disorder.

2. To identify the general features of psychological stress among mothers of Down syndrome.

3. To identify the individual differences between mothers of autism disorder and mothers of Down syndrome.

\subsection{The Importance of the Study:}

The importance of the study is highlighted through what is represented by the phenomenon of disability in general of the problems, disturbances, and pressures that fall on mothers with special needs (autism - Down syndrome) in particular and the community in the family in general.

Therefore, the study highlights its importance in that it sheds light on mothers with special needs, which represents the basic environment for building a family, and if a disability occurs to their child, it affects the parents and the special mother.

Moreover, the study seeks to contribute to an important side effect from the fields of psychological and social studies, which is psychological stress and knowledge of the most important pressures that mothers with special needs are exposed to.

\subsection{Limitations of the Study:}

The study has two limitations: -

\section{Limitation of time:}

The author chose the academic years (from 2020 to 2021) as a reasonable time to apply this study.

\section{Limitation of place:}

The study was applied and carried out in Libya -Kufra city.

\section{Literature Review}

Gallagher \& Bristol, (1989) suggest that mothers of children with autism spectrum disorders may experience higher levels of distress than mothers of children with other disabilities. For example, mothers of children with autism spectrum disorders have proven lower psychological well-being and coping compared with mothers of children with Down Syndrome, Fragile $X$, and cerebral palsy (Abbeduto et al., 2004; Blacher \& Mclntyre, 2006; Eisenhower, Baker, \& Blacher, 2005; Kasari \& Sigman, 1997). Mothers of children with autism spectrum disorders also reported increased stress and depressive symptoms compared to mothers of children with broadly defined developmental delays (Dumas et al., 1991). Two studies found comparable stress levels in mothers of children with autism spectrum disorders and externalizing disorders (Donnenberg \& Baker, 1993; Dumas et al., 1991), but no study has yet found a group of mothers with higher levels of distress than mothers of children with autism spectrum disorders. This work has contributed to our understanding of family processes and provided evidence suggesting that mothers of children with developmental disabilities, particularly autism, may be at risk of a range of challenges to their psychological functioning.

Mothers face unique challenges related to the characteristics of children with autism spectrum disorders and down syndrome. Specifically, autism and down syndrome unlike other forms of developmental disability impairs social bonding, which can be emotionally distressing for mothers. Many, but not all, children with autism spectrum disorders display very unusual patterns of language and communication, such as stereotypical speech and strange and ritualistic behaviors. Such behaviors may pose difficulties for mothers when they spend time with their children in public situations, especially when uninformed people misunderstand or misinterpret the child's behaviors. Thus, characteristics of children with autism spectrum disorders may be responsible for increased maternal stress. Alternatively, higher levels of distress in mothers of children with autism spectrum disorders may not be primarily related to the unique challenges associated with autism spectrum disorders. Shared characteristics of children with a range of developmental disabilities, such as having problematic behaviors and poor adaptive functioning, may be present to a higher degree in children with autism spectrum disorders. It may be that increased levels of these common characteristics of children, but not specific characteristics of autism, lead to increased stress in mothers of children with autism spectrum disorders.

There is mixed evidence regarding the contribution of child problem behaviors and impaired adaptive functioning to increased maternal distress. In terms of problem behaviors, research by Konstantareas and Homatidis (1989) found that self-injury was the strongest predictor of parental stress in a sample of 44 children with autism. This finding is consistent with studies of children with non-autistic developmental disabilities in which problem behaviors have emerged as the most consistent child-related source of parental distress (e.g., Baker et al., 2002; Beck et al., 2004; Hauser-Cram et al., 2001; Hodapp et al., 2003). Recent studies have also 
suggested that this pattern may be present in mothers of children with ASD (Abbeduto et al., 2004; Blacher \& McIntyre, 2006; Dumas et al., 1991; Hastings \& Brown, 2002). Another possible child characteristic that may contribute to increased parental stress is poor adaptive functioning. Parents of children with low daily living skills (a certain aspect of adaptive behavior) may face increased child-rearing responsibilities. For example, children with lower daily living skills need more help with a range of basic activities, from getting dressed, to bathing, to toileting. These increased demands may lead to increased parental pressure or psychological distress. However, the evidence is mixed regarding the relationship between adaptive function and parental distress.

Two studies have reported that better adaptive functioning in children is associated with increased maternal well-being (Fitzgerald, Birkbeck, \& Matthews, 2002; Tomanik, Harris, \& Hawkins, 2004). Two studies report no association between parental stress and adaptive skills (Beck et al., 2004; Lecavalier, Leone, \& Wiltz, 2006). In the present study, we assessed both the children's daily living skills and the child's problematic behavior, as well as the child's prognosis, as potential contributors to maternal stress.

Discussion so far has centered on understanding child characteristics as contributions to parenting stress and psychological distress. However, results may vary depending on how emotional and parental stress is measured. For example, Rodrigue, Morgan, and Geffken (1990) found that "parental stress was higher in parents of children with autism spectrum disorders compared with children with idiopathic developmental delay and typical development, but only on certain dimensions of parental stress. Perceived parental competence and marital satisfaction were lower in parents of children with autism spectrum disorders, but self-blame and disruption of finances and activities were equivalent in the autism spectrum disorders and DD groups". No group differences in family cohesion and mother-child interaction were found between groups. Beck and colleagues (2004) found that "mothers of children with general delays did not have higher levels of depression or anxiety compared with normative samples, but they did have high parenting-related stress". Greenberg and colleagues (2004) found "no differences in the overall level of optimism, depression, well-being or health among mothers of adult children with autism, Down syndrome and schizophrenia. However, mothers of children with Down syndrome reported closer relationships with their children and correlates of parental stress differed by the group". This study will investigate the phenomenon of increased maternal stress in autism and Down syndrome using present diagnostic criteria and methods and will directly investigate the characteristics of the child that may contribute to this phenomenon. We measured maternal stress in two ways; First, as it relates to maternal (referred to as ' maternal stress' in this paper) and second, to psychological distress in mothers.

The study hypotheses are (1) the general features of psychological stress among mothers of autism disorder are high, (2) the general features of psychological stress among mothers of Down syndrome disorder, and (3) there are statistically significant differences in the level of psychological stress between mothers of autism disorder and Down syndrome, and (4). there is a relationship between psychological stress among mothers of autism disorder and Down syndrome.

\section{Methodology}

\subsection{Method of the Study:}

In order to fit the objectives of the study, the comparative descriptive approach was used, which is the type of method in which the author tries to deduce the reasons for the existing differences in the condition or behavior of a group of individuals, that is, the author notes that there are differences between some groups in their variable, and tries to identify the main factor that led to the difference is this difference.

The nature of the case study is the study of psychological stress among mothers of autism and Down syndrome. It aims to verify hypotheses related to psychological stress and some other psychological symptoms, such as (response and interaction) related to psychological stress, and the basis for comparison comes from knowing the significance between the study variables.

\subsection{Variables of the study:}

The study consists of three variables; they are as follows:

1. Psychological stress: It is a force that has an internal effect that creates a state of psychological or physical imbalance within the individual

2. Down syndrome: It is a genetic condition and it occurs when a child is born with chromosomes instead of the normal, the extra chromosome, a delay in brain development, and several physical abnormalities

3. Autism: Autism or autism disorder is a developmental disorder that causes difficulties in interaction, communication, and social behavior in the individual. The patient and this does not necessarily mean a diagnosis at that age if the individual can be diagnosed with autism at any age, and although it is a chronic disorder, the treatments may improve the patient's condition and his ability to interact.

\subsection{Sample of Study:}

The study sample was drawn from mothers with autism and Down syndrome who are enrolled in the Social Solidarity Fund office in Kufra. 
Table (1) Number of sample members of mothers with autism disorder and Down syndrome.

\begin{tabular}{|l|l|l|l|l|l|l|l|}
\hline $\begin{array}{l}\text { Sample } \\
\text { selection } \\
\text { location } \\
\text { mothers autism } \\
\text { disorder }\end{array}$ & $\begin{array}{l}\text { Number } \\
\text { male }\end{array}$ & Female & $\begin{array}{l}\text { Number of mothers } \\
\text { Down syndrome } \\
\text { disorder }\end{array}$ & Male & Female & $\begin{array}{l}\text { Total } \\
\text { Number } \\
\text { of } \\
\text { Sample }\end{array}$ \\
\hline $\begin{array}{l}\text { Through } \\
\text { the names } \\
\text { of patients } \\
\text { registered } \\
\text { with the } \\
\text { Social } \\
\text { Solidarity } \\
\text { Fund in } \\
\text { Kufra. }\end{array}$ & & $\mathbf{4 8}$ & $\mathbf{1 6}$ & $\mathbf{4 4}$ & $\mathbf{8 8}$ & \\
\hline
\end{tabular}

A number of criteria have been identified for selecting the cases participating in the current study, and these criteria include the following:

1. The age range of the sample members was determined, ranging from (20-50) years, which is the common period in which psychological stress appears most often.

2. The condition should not be concurrent with a clear mental disorder or other medical problems.

3. The disabled son should have a clear disability.

\subsection{Characteristics of Sample}

- Study population: - The original population consisted of (538) mothers of patients with special needs with autism and Down syndrome, and (10\%) of them were selected for the basic sample according to the scientific rule for determining the sample size.

- Exploratory sample: The author took an exploratory sample from the study population of ten mothers, with (5) mothers with autism, and (5) mothers with Down syndrome, and their ages ranged from (10-25), with an average age of $(5,45)$, and standard deviation (5.43) to ascertain the validity of the study tools in terms of psychometric characteristics (veracity, stability) as well as the clarity of the instructions, paragraphs, and procedures in terms of meaning.

- The basic sample: The total number of patients (538) from mothers of patients with special needs with autism and Down syndrome, with an average age of (48) years and a standard deviation of (7.9), all of them are females, as for the educational level, it varied among individuals The sample, where the percentage of illiterate people (2\%), who read and write (98\%), and university education (66\%),

\subsection{Study tools and their psychometric features:}

To achieve the objectives of the current study, the researcher used the following scales:

The Psychological Stress Scale, prepared by Zaidan Ahmed Al-Sartawi and Abdel Aziz Al-Shassy, and was modified for the sample community in the State of Libya, and the validity and reliability of it was conducted through the exploratory experiment. The following is a description of each of them:

Psychological stress scale for mothers of patients with autism disorder and Down syndrome: the scale in its initial form consists of (80) items, the items were distributed on (7) dimensions, namely (psychological and organic symptoms) and it consists of (20) items feelings of despair and frustration consist of (14) items, and after psychological and cognitive problems, it consists of (13) items and a dimension family and social accompaniments consisting of (5) items. After concern for the future of the disabled son, it consists of (13) items. After problems, the independent performance of the disabled son consists of (8) items. After the inability to bear the burdens of the disabled son, it consists of (7) items, and each dimension has three alternatives to answer.

\subsection{Grades Rating:}

The subject is given a list of phrases, as well as general instructions that include the answer. These instructions have been prepared in a way that enables the subject to respond to each phrase, according to a triple assessment scale using the Likert method, that 
is, on a gradient of (3) points to assess the intensity and frequency or to assess the selected characteristics of psychological stress, Meaning, the scores range from (3-1), where:

- $\quad$ Answer (1) refers to low or negative perceptions.

- Answer (3) refers to high or positive perceptions.

- A high degree indicates the absence of good psychological pressure, while a low degree indicates the level of psychological stress.

- Positive statements give the values $(, 3,2,1)$ respectively, while the gradation of these values is reversed in the case of negative statements.

\subsection{Psychometric properties of the scale:}

The Department of Psychological Stress evaluated the standard characteristics of this scale on heterogeneous samples of mothers of patients with autism and Down syndrome on the Psychological Stress Scale No Matters and the results showed that the scale is characterized by very high psychometric properties.

\section{1- Reliability coefficient:}

Reliability was estimated using Crow-Nbach's alpha coefficient, and the following table shows alpha coefficient values for the main domains and sub-factors of the psychological stress scale for patients with autism and Down syndrome.

Table (2): Alpha stability coefficient for the main domains and sub-factors of the stress scale

\begin{tabular}{|c|c|c|c|c|c|}
\hline No & $\begin{array}{l}\text { Principal domains and } \\
\text { sub-factors }\end{array}$ & $\begin{array}{l}\text { Alpha Stability } \\
\text { Coefficient }\end{array}$ & No & $\begin{array}{l}\text { Principal domains and } \\
\text { sub-factors }\end{array}$ & $\begin{array}{l}\text { Alpha Stability } \\
\text { Coefficient }\end{array}$ \\
\hline 1 & $\begin{array}{l}\text { Psychological and organic } \\
\text { symptoms }\end{array}$ & 0.73 & 41 & $\begin{array}{l}\text { Psychological and cognitive } \\
\text { problems }\end{array}$ & 0.75 \\
\hline 2 & $\begin{array}{l}\text { Psychological and organic } \\
\text { symptoms }\end{array}$ & 0.76 & 42 & $\begin{array}{l}\text { Psychological and cognitive } \\
\text { problems }\end{array}$ & 0.74 \\
\hline 3 & $\begin{array}{l}\text { Psychological and organic } \\
\text { symptoms }\end{array}$ & 0.92 & 43 & $\begin{array}{l}\text { Psychological and cognitive } \\
\text { problems }\end{array}$ & 0.80 \\
\hline 4 & $\begin{array}{l}\text { Psychological and organic } \\
\text { symptoms }\end{array}$ & 0.63 & 44 & $\begin{array}{l}\text { Psychological and cognitive } \\
\text { problems }\end{array}$ & 0.71 \\
\hline 5 & $\begin{array}{l}\text { Psychological and organic } \\
\text { symptoms }\end{array}$ & 0.95 & 45 & $\begin{array}{l}\text { Psychological and cognitive } \\
\text { problems }\end{array}$ & 0.83 \\
\hline 6 & $\begin{array}{l}\text { Psychological and organic } \\
\text { symptoms }\end{array}$ & 0.83 & 46 & $\begin{array}{l}\text { Psychological and cognitive } \\
\text { problems }\end{array}$ & 0.76 \\
\hline 7 & $\begin{array}{l}\text { Psychological and organic } \\
\text { symptoms }\end{array}$ & 0.73 & 47 & $\begin{array}{l}\text { Psychological and cognitive } \\
\text { problems }\end{array}$ & 0.87 \\
\hline 8 & $\begin{array}{l}\text { Psychological and organic } \\
\text { symptoms }\end{array}$ & 0.70 & 48 & $\begin{array}{l}\text { Psychological and cognitive } \\
\text { problems }\end{array}$ & 0.64 \\
\hline 9 & $\begin{array}{l}\text { Psychological and organic } \\
\text { symptoms }\end{array}$ & 0.76 & 49 & $\begin{array}{l}\text { Psychological and cognitive } \\
\text { problems }\end{array}$ & 0.87 \\
\hline 10 & $\begin{array}{l}\text { Psychological and organic } \\
\text { symptoms }\end{array}$ & 0.87 & 50 & $\begin{array}{l}\text { Psychological and cognitive } \\
\text { problems }\end{array}$ & $\begin{array}{l}0.80 \\
0.74\end{array}$ \\
\hline 11 & $\begin{array}{l}\text { Psychological and organic } \\
\text { symptoms }\end{array}$ & 0.82 & 51 & $\begin{array}{l}\text { Psychological and cognitive } \\
\text { problems }\end{array}$ & 0.76 \\
\hline 12 & $\begin{array}{l}\text { Psychological and organic } \\
\text { symptoms }\end{array}$ & 0.89 & 52 & $\begin{array}{l}\text { Psychological and cognitive } \\
\text { problems }\end{array}$ & 0.81 \\
\hline
\end{tabular}




\begin{tabular}{|c|c|c|c|c|c|}
\hline 13 & $\begin{array}{l}\text { Psychological and organic } \\
\text { symptoms }\end{array}$ & 0.87 & 53 & $\begin{array}{l}\text { Psychological and cognitive } \\
\text { problems }\end{array}$ & 0.89 \\
\hline 14 & $\begin{array}{l}\text { Psychological and organic } \\
\text { symptoms }\end{array}$ & 0.77 & 54 & $\begin{array}{l}\text { Psychological and cognitive } \\
\text { problems }\end{array}$ & 0.75 \\
\hline 15 & $\begin{array}{l}\text { Psychological and organic } \\
\text { symptoms }\end{array}$ & 0.89 & 55 & $\begin{array}{l}\text { Psychological and cognitive } \\
\text { problems }\end{array}$ & 0.74 \\
\hline 16 & $\begin{array}{l}\text { Psychological and organic } \\
\text { symptoms }\end{array}$ & 0.81 & 56 & $\begin{array}{l}\text { Psychological and cognitive } \\
\text { problems }\end{array}$ & 0.73 \\
\hline 17 & $\begin{array}{l}\text { Psychological and organic } \\
\text { symptoms }\end{array}$ & 0.75 & 57 & $\begin{array}{l}\text { Psychological and cognitive } \\
\text { problems }\end{array}$ & 0.70 \\
\hline 18 & $\begin{array}{l}\text { Psychological and organic } \\
\text { symptoms }\end{array}$ & 0.74 & 58 & $\begin{array}{l}\text { Psychological and cognitive } \\
\text { problems }\end{array}$ & 0.76 \\
\hline 19 & $\begin{array}{l}\text { Psychological and organic } \\
\text { symptoms }\end{array}$ & 0.80 & 59 & $\begin{array}{l}\text { Psychological and cognitive } \\
\text { problems }\end{array}$ & 0.87 \\
\hline 20 & $\begin{array}{l}\text { Psychological and organic } \\
\text { symptoms }\end{array}$ & 0.71 & 60 & $\begin{array}{l}\text { Psychological and cognitive } \\
\text { problems }\end{array}$ & 0.82 \\
\hline 21 & $\begin{array}{l}\text { Psychological and organic } \\
\text { symptoms }\end{array}$ & 0.83 & 61 & $\begin{array}{l}\text { Psychological and cognitive } \\
\text { problems }\end{array}$ & 0.89 \\
\hline 22 & $\begin{array}{l}\text { Psychological and organic } \\
\text { symptoms }\end{array}$ & 0.76 & 62 & $\begin{array}{l}\text { Psychological and cognitive } \\
\text { problems }\end{array}$ & 0.87 \\
\hline 23 & $\begin{array}{l}\text { Psychological and organic } \\
\text { symptoms }\end{array}$ & 0.87 & 63 & $\begin{array}{l}\text { Psychological and cognitive } \\
\text { problems }\end{array}$ & 0.77 \\
\hline 24 & $\begin{array}{l}\text { Psychological and organic } \\
\text { symptoms }\end{array}$ & 0.64 & 64 & $\begin{array}{l}\text { Psychological and cognitive } \\
\text { problems }\end{array}$ & 0.89 \\
\hline 25 & $\begin{array}{l}\text { Psychological and organic } \\
\text { symptoms }\end{array}$ & 0.87 & 65 & $\begin{array}{l}\text { Psychological and cognitive } \\
\text { problems }\end{array}$ & 0.81 \\
\hline 26 & $\begin{array}{l}\text { Psychological and organic } \\
\text { symptoms }\end{array}$ & $\begin{array}{l}0.80 \\
0.74\end{array}$ & 66 & $\begin{array}{l}\text { Psychological and cognitive } \\
\text { problems }\end{array}$ & 0.73 \\
\hline 27 & $\begin{array}{l}\text { Psychological and organic } \\
\text { symptoms }\end{array}$ & 0.76 & 67 & $\begin{array}{l}\text { Psychological and cognitive } \\
\text { problems }\end{array}$ & $\mid 0.70$ \\
\hline 28 & $\begin{array}{l}\text { Psychological and organic } \\
\text { symptoms }\end{array}$ & 0.81 & 68 & $\begin{array}{l}\text { Psychological and cognitive } \\
\text { problems }\end{array}$ & 0.76 \\
\hline 29 & $\begin{array}{l}\text { Psychological and organic } \\
\text { symptoms }\end{array}$ & 0.89 & 69 & $\begin{array}{l}\text { Psychological and cognitive } \\
\text { problems }\end{array}$ & 0.87 \\
\hline 30 & $\begin{array}{l}\text { Psychological and organic } \\
\text { symptoms }\end{array}$ & 0.92 & 70 & $\begin{array}{l}\text { Psychological and cognitive } \\
\text { problems }\end{array}$ & 0.82 \\
\hline 31 & $\begin{array}{l}\text { Psychological and organic } \\
\text { symptoms }\end{array}$ & 0.63 & 71 & $\begin{array}{l}\text { Psychological and cognitive } \\
\text { problems }\end{array}$ & 0.89 \\
\hline
\end{tabular}




\begin{tabular}{|c|c|c|c|c|c|}
\hline 32 & $\begin{array}{l}\text { Psychological and organic } \\
\text { symptoms }\end{array}$ & 0.95 & 72 & $\begin{array}{l}\text { Psychological and cognitive } \\
\text { problems }\end{array}$ & 0.87 \\
\hline 33 & $\begin{array}{l}\text { Psychological and organic } \\
\text { symptoms }\end{array}$ & 0.83 & 73 & $\begin{array}{l}\text { Psychological and cognitive } \\
\text { problems }\end{array}$ & 0.77 \\
\hline 34 & $\begin{array}{l}\text { Psychological and organic } \\
\text { symptoms }\end{array}$ & 0.73 & 74 & $\begin{array}{l}\text { Psychological and cognitive } \\
\text { problems }\end{array}$ & 0.89 \\
\hline 35 & $\begin{array}{l}\text { Psychological and organic } \\
\text { symptoms }\end{array}$ & 0.70 & 75 & $\begin{array}{l}\text { Psychological and cognitive } \\
\text { problems }\end{array}$ & 0.81 \\
\hline 36 & $\begin{array}{l}\text { Psychological and organic } \\
\text { symptoms }\end{array}$ & 0.76 & 76 & $\begin{array}{l}\text { Psychological and cognitive } \\
\text { problems }\end{array}$ & 0.87 \\
\hline 37 & $\begin{array}{l}\text { Psychological and organic } \\
\text { symptoms }\end{array}$ & 0.77 & 78 & $\begin{array}{l}\text { Psychological and cognitive } \\
\text { problems }\end{array}$ & 0.77 \\
\hline 38 & $\begin{array}{l}\text { Psychological and organic } \\
\text { symptoms }\end{array}$ & 0.92 & 79 & $\begin{array}{l}\text { Psychological and cognitive } \\
\text { problems }\end{array}$ & 0.77 \\
\hline 39 & $\begin{array}{l}\text { Psychological and organic } \\
\text { symptoms }\end{array}$ & 0.81 & 80 & $\begin{array}{l}\text { Psychological and cognitive } \\
\text { problems }\end{array}$ & 0.89 \\
\hline 40 & $\begin{array}{l}\text { Psychological and organic } \\
\text { symptoms }\end{array}$ & 0.73 & 54 & $\begin{array}{l}\text { Psychological and cognitive } \\
\text { problems }\end{array}$ & 0.81 \\
\hline
\end{tabular}

From the previous table, it is clear that alpha values are high and satisfactory for all domains and sub-factors of the quality of life scale, which indicates good stability of the scale.

\subsection{The validity of scale:}

The validity of the scale was estimated using the following methods:

\subsubsection{Internal consistency validity:}

The internal consistency coefficients were calculated as an indicator of validity by calculating the correlation between the degree on the sub-factor and the total score. Table (3) shows the values of the correlation coefficients between the factor and the items that fall under it.

Table (3) Correlation between the item and the total score of the psychological stress scale subscales

\begin{tabular}{|l|l|l|l|}
\hline \multicolumn{1}{|l|}{ Items } & Correlation coefficient & Items & correlation coefficient \\
\hline & & & The ability to move \\
\hline 1 & & & \\
\hline 2 & 0.88 & 44 & 0.76 \\
\hline 3 & 0.75 & 45 & 0.76 \\
\hline 4 & 0.80 & 46 & 0.82 \\
\hline 5 & 0.69 & 47 & 0.75 \\
\hline 6 & 0.70 & 48 & 0.86 \\
\hline 7 & 0.96 & 49 & 0.68 \\
\hline 8 & 0.63 & 50 & 0.63 \\
\hline 9 & 0.78 & 51 & 0.73 \\
\hline 10 & 0.69 & 52 & 0.77 \\
\hline 11 & 0.63 & 53 & 0.82 \\
\hline 12 & 0.97 & 54 & 0.82 \\
\hline 13 & 0.56 & 55 & 0.90 \\
\hline
\end{tabular}




\begin{tabular}{|c|c|c|c|}
\hline 14 & 0.60 & 57 & 0.50 \\
\hline 15 & 0.73 & 58 & 0.78 \\
\hline 16 & 0.78 & 59 & 0.83 \\
\hline 17 & 0.78 & 60 & 0.82 \\
\hline 18 & 0.84 & 61 & 0.81 \\
\hline 19 & 0.73 & 62 & 0.84 \\
\hline 20 & 0.86 & 63 & \begin{tabular}{|l|}
0.78 \\
\end{tabular} \\
\hline 21 & 0.88 & 64 & 0.70 \\
\hline 22 & 0.74 & 65 & \begin{tabular}{|l|}
0.69 \\
\end{tabular} \\
\hline 23 & 0.48 & 66 & 0.68 \\
\hline 24 & 0.72 & 67 & 0.58 \\
\hline 25 & 0.66 & 68 & 0.69 \\
\hline 26 & 0.69 & 69 & 0.75 \\
\hline 27 & 0.79 & 70 & \begin{tabular}{|l|l}
0.78 \\
\end{tabular} \\
\hline 28 & 0.43 & 71 & 0.71 \\
\hline 29 & 0.40 & 72 & 0.69 \\
\hline 30 & 0.65 & 73 & 0.67 \\
\hline 31 & 0.58 & 74 & 0.90 \\
\hline 32 & 0.69 & 75 & \begin{tabular}{|l|l}
0.67 \\
\end{tabular} \\
\hline 33 & 0.71 & 76 & 0.60 \\
\hline 34 & 0.76 & 78 & 0.75 \\
\hline 35 & 0.83 & 79 & 0.59 \\
\hline 36 & 0.76 & 80 & 0.85 \\
\hline 37 & 0.83 & 44 & 0.66 \\
\hline 38 & 0.78 & 45 & \begin{tabular}{|l|}
0.77 \\
\end{tabular} \\
\hline 39 & 0.80 & 46 & 0.73 \\
\hline 40 & 0.76 & 47 & 0.66 \\
\hline 41 & 0.77 & 48 & 0.67 \\
\hline 42 & 0.85 & 49 & 0.78 \\
\hline 43 & 0.80 & 50 & 0.73 \\
\hline
\end{tabular}

The previous table shows that all correlation coefficients are significant at the significance level (0.01), which is a high level and is a good indicator of the validity of the scale.

\section{$0.9126-$}

\subsection{Statistical Methods:}

Statistical packages (SPSS) program was used, which are:

1. Percentage.

2. Arithmetic averages.

3. Correlation coefficient.

4. T. Test to indicate differences.

4. Data Analysis and Discussion:

4.1 The statistical results of the study, their interpretation, and discussion 


\subsubsection{The results of testing the validity of the first hypothesis, their interpretation, and discussion.}

This hypothesis states that "the general features of psychological stress among mothers of autism disorder are high."

To verify the validity of this hypothesis, the Pearson correlation coefficient was calculated between the general characteristics of psychological stress among mothers of autism. The following table shows this procedure:

Table (4): It shows the arithmetic averages, the calculated ( $t$ ) value, and the level of significance

\begin{tabular}{|l|l|l|l|l|l|l|l|}
\hline $\begin{array}{l}\text { Sample } \\
\text { size }\end{array}$ & $\begin{array}{l}\text { Theoretical } \\
\text { mean }\end{array}$ & $\begin{array}{l}\text { Arithmetic } \\
\text { mean }\end{array}$ & $\begin{array}{l}\text { Standard } \\
\text { deviation }\end{array}$ & $\begin{array}{l}\text { Degree of } \\
\text { freedom }\end{array}$ & T-value & $\begin{array}{l}\text { Significance } \\
\text { level }\end{array}$ & Conclusion \\
\hline $\mathbf{8 8}$ & 96 & 82.66 & 17.43 & 86 & 21.26 & 0.01 & $\begin{array}{l}\text { The general } \\
\text { poison } \\
\text { of } \\
\text { psychological } \\
\text { stress among } \\
\text { mothers of } \\
\text { of } \\
\text { autism } \\
\text { disorder } \\
\text { characterized } \\
\text { by high. }\end{array}$ \\
\hline
\end{tabular}

$$
(\mathrm{n}=88)
$$

${ }^{*}$ At the level of significance (0.05). ${ }^{* *}$ At the level of significance (0.01).

From Table (4), it is clear that the theoretical mean (96), the arithmetic mean (82.66), the standard deviation (17.43), the degree of freedom (86), the value of (T) (21.26), the significance level (0.01), which indicates that the general features of psychological stress among mothers of a disorder. Autism is on the rise.

\subsubsection{The results of the second hypothesis validity test, their interpretation, and discussion.}

This hypothesis states that "the general characteristics of psychological stress among mothers of Down syndrome are low."

To verify the validity of this hypothesis, the Pearson correlation coefficient was calculated between the general characteristics of psychological stress among mothers of Down syndrome disorder. The following table shows this procedure:

Table (5): It shows the arithmetic averages, the calculated (t) value, and the level of significance

\begin{tabular}{|l|l|l|l|l|l|l|l|}
\hline $\begin{array}{l}\text { Sample } \\
\text { size }\end{array}$ & $\begin{array}{l}\text { Theoretical } \\
\text { mean }\end{array}$ & $\begin{array}{l}\text { Arithmetic } \\
\text { mean }\end{array}$ & $\begin{array}{l}\text { Standard } \\
\text { deviation }\end{array}$ & $\begin{array}{l}\text { Degree of } \\
\text { freedom }\end{array}$ & T-value & $\begin{array}{l}\text { Significance } \\
\text { level }\end{array}$ & Conclusion \\
\hline $\mathbf{8 8}$ & 60 & 92.66 & 16.43 & 86 & 22.26 & 0.01 & $\begin{array}{l}\text { The general } \\
\text { characteristics } \\
\text { of } \\
\text { psychological } \\
\text { stress among } \\
\text { mothers } \\
\text { of } \\
\text { Down } \\
\text { syndrome } \\
\text { disorder are } \\
\text { low. }\end{array}$ \\
\hline
\end{tabular}

$$
(n=88)
$$

*At the level of significance (0.05). ** At the level of significance (0.01).

From Table (5), it is clear that the theoretical mean (96), the arithmetic mean (82.66), the standard deviation (17.43), the degree of freedom (86), the value of $(T)$ (21.26), the significance level (0.01), which indicates that the general features of psychological stress among mothers of a disorder Autism are down. 
4.1.3 The results of the third hypothesis validity test, their interpretation, and discussion.

This hypothesis states that "there are statistically significant differences in the level of psychological stress between mothers of autism and Down syndrome.

To verify the validity of this hypothesis, arithmetic means, standard deviations, and the value of (t) Pearson's correlation coefficient was used to find statistically significant differences in the level of psychological stress between mothers of autism and Down syndrome. The following table illustrates this procedure:

Table (6): Explains the differences between the symptoms of autism and Down syndrome on the psychological stress scale

\begin{tabular}{|c|c|c|c|c|c|c|c|}
\hline \multicolumn{2}{|c|}{ Autistic mothers $(n)=$} & \multicolumn{2}{|c|}{$\begin{array}{l}\text { Down syndrome mothers } \\
\text { (n) }=\end{array}$} & $\begin{array}{l}\text { degree of } \\
\text { freedom }\end{array}$ & $\begin{array}{l}(\mathrm{T}- \\
\text { value })\end{array}$ & $\begin{array}{l}\text { Significance } \\
\text { level }\end{array}$ & Conclusion \\
\hline $\begin{array}{l}\text { Arithmetic } \\
\text { mean }\end{array}$ & $\begin{array}{l}\text { Standard } \\
\text { deviation }\end{array}$ & $\begin{array}{l}\text { Arithmetic } \\
\text { mean }\end{array}$ & $\begin{array}{l}\text { Standard } \\
\text { deviation }\end{array}$ & & & & $\begin{array}{l}\text { The differences } \\
\text { are statistically } \\
\text { significant in } \\
\text { the level of }\end{array}$ \\
\hline 82.77 & 14.65 & 77.98 & 15.02 & 86 & 22.26 & 0.01 & $\begin{array}{l}\text { stress between } \\
\text { mothers of } \\
\text { autism } \\
\text { disorder and } \\
\text { Down } \\
\text { syndrome. }\end{array}$ \\
\hline
\end{tabular}

It is noted from Table No. (6), which shows the t-test for two independent samples to find out the differences between mothers of children with autism disorder and mothers of children with Down syndrome on the psychological stress scale, and that the average of mothers of children with autism disorder is (82.77) and the average of mothers of children with the syndrome is (77.98). (82.77) standard deviation (14.65) degree of freedom (86) value (T) (22.26) in comparison between the two averages, the significance level is (0.01), which means that there are differences between mothers of children with autism disorder and mothers of children with Down syndrome on the psychological stress scale.

\subsubsection{The results of the fourth hypothesis validity test, their interpretation, and discussion.}

This hypothesis states that "there is a relationship between psychological stress among mothers of autism and Down syndrome.

To verify the validity of this hypothesis, the Pearson correlation coefficient was calculated between the scores of the sample members on the psychological stress scale, with signs of autism and Down syndrome. The following table shows the result of this procedure:

Table (7): Explains the relationship between psychological stress in mothers of autism disorder and Down syndrome.

\begin{tabular}{|l|l|l|l|}
\hline Sample size & $\begin{array}{l}\text { Pearson correlation } \\
\text { value }\end{array}$ & Significance level & Conclusion \\
\hline $\mathbf{8 8}$ & $\mathbf{0 . 5 9}$ & $\mathbf{0 . 0 1}$ & $\begin{array}{l}\text { There is a relationship } \\
\text { between psychological } \\
\text { stress among mothers of } \\
\text { autism and Down } \\
\text { syndrome and }\end{array}$ \\
\hline
\end{tabular}

It is noted from Table No. (7), which shows the Pearson correlation coefficient to know the relationship between psychological stress among mothers of autism disorder and Down syndrome, and this is a function at a level of significance (0.01), which indicates the existence of a relationship between psychological stress among mothers of autism and Down syndrome.

\subsection{Discuss the search results}




\subsubsection{Discussing the first hypothesis.}

To choose the validity of the first hypothesis, which states, "The general features of psychological stress among mothers of autism disorder are high, and by reference to Table No. (4), which clarified that the theoretical average (96), the arithmetic mean (82.66), the standard deviation (17.43), the degree of freedom (86) is a value of (C) (21.26) significance level (0.01), which indicates that the general features of psychological stress among mothers of autism disorder are high, and this can be explained in the light of These results agreed with the study of Klaman (Noor Al-Huda Omar / 2018), whose results were that the level of life of the fathers and mothers with intellectual disabilities is high, and they also agreed with the Raindi study (2007), whose results were high with the level of the psychological relationship and the pressures of social values, as indicated by Al-Wasta (2013) that it is severe psychological crises and emotional trauma The resulting relationship between the mother and the autistic child is characterized by high psychological pressure.

The author also sees that the mothers of autistic children are higher in psychological pressure so that autistic children are more mobile and defiant, and they form constant pressure on the house, and therefore care is more than the crisis, this leads to a high level of psychological pressure.

\subsubsection{Discussing the second hypothesis.}

To choose the validity of the second hypothesis, which states, "The general features of psychological stress among mothers of Down syndrome are characterized by lowness. And by referring to Table No. (5), which clarified the theoretical mean (96), the arithmetic mean (82.66), the standard deviation (17.43), the degree of freedom (86) the value of (C) (21.26), the significance level (0.01), which indicates that the general features of psychological stress among mothers of autism disorder are low, and this can be explained in the light of these results agreed with the results of the study of Naday Issa (2017), whose results were that there is a decrease in psychological stress among mothers of children with mental disabilities.

The study of Ali Faraj and Nahla Ahmed (2015) indicated that the psychological stress of mothers of children with mental disabilities was reduced according to the variables of the degree of disability and economic status.

The author also sees that mothers of children with Down syndrome have lower psychological pressures, as children with Down syndrome are less mobile and aggressive, and their mothers do not suffer from pressure and do not need a great degree of care for them. This leads to a lower level of psychological pressure.

\subsubsection{Discussing the third hypothesis.}

To choose the validity of the third hypothesis, which states "there are statistically significant differences in the level of psychological stress between mothers of autism and Down syndrome."

Referring to Table No. (6), which shows the t-test for two independent samples to find out the differences between mothers of children with autism disorder and mothers of children with Down syndrome on the psychological stress scale, and that the average of mothers of children with autism disorder (82.77) and the average of mothers of children with the syndrome (77.98), the theoretical average becomes clear (96) Arithmetic mean (82.66) Standard deviation (17.43) Degree of freedom (86) Value (T) (

In comparison between the two averages, it is clear that the significance level is $(0.01)$, which means that there are differences between mothers of children with autism disorder and mothers of children with Down syndrome on the psychological stress scale, and this can be explained by

These results agreed with the results of the study of Nour Al-Huda Omar (2016), whose results were that the life standard of fathers and mothers with intellectual disabilities is high.

These results agreed with the results of the study of Naday Issa (2017), whose results were that there is a decrease in psychological stress among mothers of children with mental disabilities.

The author also sees that mothers of children with autism are higher in psychological stress. The author also observes that mothers of children with Down syndrome have lower psychological pressures.

\subsubsection{Discussing the fourth hypothesis.}

To choose the validity of the third hypothesis, which states: "There is a relationship between psychological stress among mothers of autism disorder and Down syndrome. 
Referring to Table No. (7), which shows and shows the Pearson correlation coefficient to know the relationship between psychological stress among mothers Autism and Down syndrome, and this function is at a significance level (0.01), which indicates a relationship between psychological stress among mothers of autism and Down syndrome. These results agreed with the results of the study of Mizan (2014), which is that there is a stylistic relationship between psychological stress

The author also sees that there is a relationship between psychological stress among mothers of autism and Down syndrome.

\section{Conclusions and Recommendations}

This study was carried out in Libya with psychological stress among mothers of children with special needs autism spectrum disorder and down syndrome. To reduce the stress levels of mothers of children with autism, we always suggest having a support group, making progress in coaching mothers' skills, improving skills, and hiring nannies as a support group in the future. For mothers with children with Down syndrome, social support is defined as information directed at the person so that he or she believes that people like him or her are needed, valued, and important in the system of reciprocal communication. Examples of social support include spouses, family or friends, and support groups.

Parents believe that getting adequate social support for themselves and their children is very important in adapting the family to the difficulty they are in. Social support can also reduce the impact of stress and depression in mothers of children with autism and Down syndrome, which means that social support plays an important role in protecting the mental health of parents with children's difficulties.

\section{References}

[1] Abbeduto, L., Seltzer, M. M., Shattuck, P., Krauss, M. W., Orsmond, G., \& Murphy, M. M. (2004). Psychological well-being and coping in mothers of youths with autism, down syndrome, orfragile X syndrome. American journal on mental retardation, 109(3), $237-254$.

[2] Baker, B. L., Blacher, J., Crnic, K. A., \& Edelbrock, C. (2002). Behavior problems and parenting stress in families of three-year-old children with and without developmental delays. American journal on mental retardation, 107(6), 433-444.

[3] Beck, A., Daley, D., Hastings, R. P., \& Stevenson, J. (2004). Mothers' expressed emotion towards children with and without intellectual disabilities. Journal of Intellectual Disability Research, 48(7), 628-638.

[4] Blacher, J., \& Mclntyre, L. L. (2006). Syndrome specificity and behavioural disorders in young adults with intellectual disability: Cultural differences in family impact. Journal of Intellectual Disability Research, 50(3), 184-198.

[5] Donenberg, G., \& Baker, B. L. (1993). The impact of young children with externalizing behaviors on their families. Journal of abnormal child psychology, 21(2), 179-198.

[6] Dumas, J. E., Wolf, L. C., Fisman, S. N., \& Culligan, A. (1991). Parenting stress, child behavior problems, and dysphoria in parents of children with autism, Down syndrome, behavior disorders, and normal development. Exceptionality: A Special Education Journal, 2(2), 97-110.

[7] Eisenhower, A. S., Baker, B. L., \& Blacher, J. (2005). Preschool children with intellectual disability: syndrome specificity, behaviour problems, and maternal well-being. Journal of intellectual disability research, 49(9), 657-671.

[8] Fitzgerald, M., Birkbeck, G., \& Matthews, P. (2002). Maternal burden in families with children with autistic spectrum disorder. The Irish Journal of Psychology.

[9] Gallagher, J. J., \& Bristol, M. A. R. I. E. (1989). Families of young handicapped children. Handbook of special education: Research and practice, 3, 295-317.

[10] Gray, J. A. (1987). The psychology of fear and stress. Cambridge University Press. New York.

[11] Greenberg, J. S., Seltzer, M. M., Krauss, M. W., Chou, R. J. A., \& Hong, J. (2004). The effect of quality of the relationship between mothers and adult children with schizophrenia, autism, or Down syndrome on maternal well-being: The mediating role of optimism. American Journal of Orthopsychiatry, 74(1), 14-25.

[12] Hastings, R. P., \& Brown, T. (2002). Behavior problems of children with autism, parental self-efficacy, and mental health. American journal on mental retardation, 107(3), 222-232.

[13] Hauser-Cram, P., Warfield, M. E., Shonkoff, J. P., \& Krauss, M. W. (2001). I. Introduction. Monographs of the society for research in child development, 66(3), 1-5.

[14] Hodapp, R. M., Ricci, L. A., Ly, T. M., \& Fidler, D. J. (2003). The effects of the child with Down syndrome on maternal stress. British Journal of Developmental Psychology, 21(1), 137-151.

[15] Johnson, N., Frenn, M., Feetham, S., \& Simpson, P. (2011). Autism spectrum disorder: parenting stress, family functioning and health-related quality of life. Families, systems, \& health, 29(3), 232.

[16] Kasari, C., \& Sigman, M. (1997). Linking parental perceptions to interactions in young children with autism. Journal of autism and developmental disorders, 27(1), 39-57.

[17] Konstantareas, M. M., \& Homatidis, S. (1989). Assessing child symptom severity and stress in parents of autistic children. Journal of Child Psychology and Psychiatry, 30(3), 459-470.

[18] Konstantareas, M. M., Homatidis, S., \& Plowright, C. M. S. (1992). Assessing resources and stress in parents of severely dysfunctional children through the Clarke modification of Holroyd's Questionnaire on Resources and Stress. Journal of Autism and Developmental Disorders, 22(2), 217-234. 
[19] Lecavalier, L., Leone, S., \& Wiltz, J. (2006). The impact of behaviour problems on caregiver stress in young people with autism spectrum disorders. Journal of intellectual disability research, 50(3), 172-183.

[20] Rodrigue, J. R., Morgan, S. B., \& Geffken, G. (1990). Families of autistic children: Psychological functioning of mothers. Journal of clinical child psychology, 19(4), 371-379.

[21] Sanders, J. L., \& Morgan, S. B. (1997). Family stress and adjustment as perceived by parents of children with autism or Down syndrome: Implications for intervention. Child \& Family Behavior Therapy, 19(4), 15-32.

[22] Schieve, L. A., Blumberg, S. J., Rice, C., Visser, S. N., \& Boyle, C. (2007). The relationship between autism and parenting stress. Pediatrics, 119(Supplement 1), S114-S121.

[23] Tomanik, S., Harris, G. E., \& Hawkins, J. (2004). The relationship between behaviours exhibited by children with autism and maternal stress. Journal of Intellectual and Developmental Disability, 29(1), 16-26.

[24] Woodgate, R. L., Ateah, C., \& Secco, L. (2008). Living in a world of our own: The experience of parents who have a child with autism. Qualitative health research, 18(8), 1075-1083. 